\title{
Heat Transfer Analysis of Passive Residual Heat Removal Heat Exchanger under Natural Convection Condition in Tank
}

\author{
Qiming Men, Xuesheng Wang, Xiang Zhou, and Xiangyu Meng \\ School of Mechanical and Power Engineering, East China University of Science and Technology, Room 637, Building 17, \\ 130 Meilong Road, Shanghai 200237, China
}

Correspondence should be addressed to Xuesheng Wang; wangxs@ecust.edu.cn

Received 15 May 2014; Revised 3 November 2014; Accepted 3 November 2014; Published 20 November 2014

Academic Editor: Borut Mavko

Copyright (C) 2014 Qiming Men et al. This is an open access article distributed under the Creative Commons Attribution License, which permits unrestricted use, distribution, and reproduction in any medium, provided the original work is properly cited.

\begin{abstract}
Aiming at the heat transfer calculation of the Passive Residual Heat Removal Heat Exchanger (PRHR HX), experiments on the heat transfer of $\mathrm{C}$-shaped tube immerged in a water tank were performed. Comparisons of different correlation in literatures with the experimental data were carried out. It can be concluded that the Dittus-Boelter correlation provides a best-estimate fit with the experimental results. The average error is about $0.35 \%$. For the tube outside, the McAdams correlations for both horizontal and vertical regions are best-estimated. The average errors are about $0.55 \%$ for horizontal region and about $3.28 \%$ for vertical region. The tank mixing characteristics were also investigated in present work. It can be concluded that the tank fluid rose gradually which leads to a thermal stratification phenomenon.
\end{abstract}

\section{Introduction}

The AP set reactors are pressurized water reactors designed to use a natural circulation heat exchanger as the safety related means of removing core decay heat and sensible heat following certain design basis events [1]. The Passive residual heat removal heat exchanger (PRHR HX) removes core decay heat to mitigate loss of heat sink events which depressurizes the system. It transfers heat from the primary side to the containment by heating the water in the In-containment Refueling Water Storage Tank (IRWST). The PRHR HX consists of a C-shaped heat exchanger tube bundle submerged in the IRWST [2].

Natural circulation flow is developed from the density difference of the cold water in the PRHR tubes above the reactor core and the hot water in the inlet line to the heat exchanger. The heat transfer on the outer tube surface is natural convection and subcooled boiling in the initial operation stage and gradually becomes saturation boiling along with the process of heating [3]. Because of the large temperature difference across the heater exchanger tubes, high Grashof number natural convection will occur along the tube outer surfaces [4].
Yonomoto et al. [3] carried out an experimental investigation to simulate small-break loss-of-coolant accidents in the reactor using the ROSA-V Large-scale Test Facility. The PRHR HX heat transfer performance in the experiment was analyzed by applying heat transfer correlations available in the literature to the PRHR HX tubes. Jeong et al. [5] developed a multidimensional thermal-hydraulic system code MARS to analyse the thermal hydraulic of the Passive Residual Heat Removal System (PRHRS) of the SMART-P. Chung et al. $[6,7]$ investigated the natural circulation in the PRHRS for an integral type reactor and calculated results using the MARS code. According to Chung's work, the MARS code predicts reasonably well the characteristics of the natural circulation in the PRHRS. It is considerable that different heat transfer correlations of tube inner and outer surfaces are used in Yonomoto's paper and MARS code but the reason why the earlier investigators choose the correlations is not mentioned in their paper.

The main purpose of this study is to determine the applicability of different heat transfer correlations for the PRHR HX design. The secondary objective is to investigate the IRWST mixing characteristics in the IRWST. As mentioned above, natural convection heat transfer on outer tube surface 


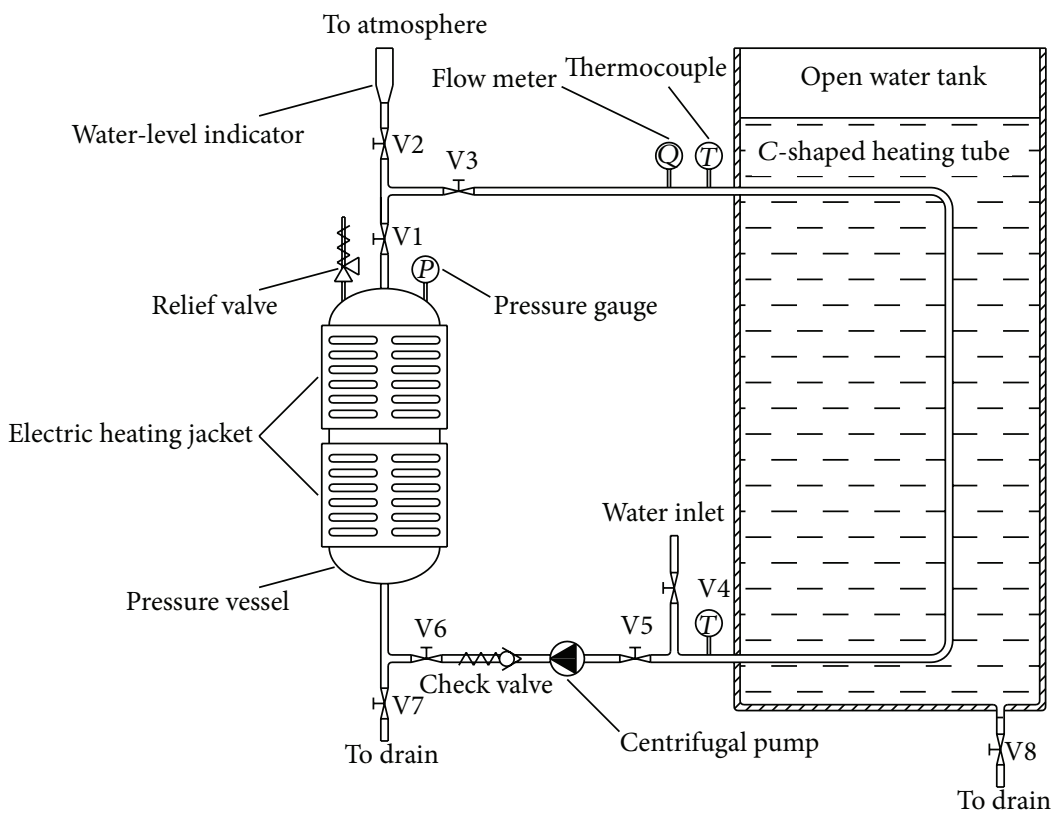

FIGURE 1: Schematic diagram of experimental system.

plays a significant role in the PRHR HX, especially in the initial stage. Boiling on the tube outer surface has not been considered in present work; all these results in this paper are for the condition of natural convection on the outer surface.

\section{Experimental Setup}

The experimental apparatus (see Figure 1) was built to investigate the thermal performance of PRHR HX while natural convection occurred in IRWST. It mainly consisted of a cylinder pressure vessel, an open water tank, a C-shaped heat pipe, two electric heating jackets, some wall and liquid thermocouples, and a centrifugal pump. Primary system core decay heat was substituted by hot water generated in the pressure vessel. A pressure gauge and a relief valve were installed on the top of the pressure vessel to monitor the pressure and provide overpressure protection. The range of the pressure gauge is from 0 to $0.6 \mathrm{MPa}$ and the reading accuracy of it is $0.05 \mathrm{MPa}$. The IRWST was modeled by a volume $(\pi / 4)\left(0.6^{2} \times 1.5\right) \mathrm{m}^{3}$ cylindrical tank filled with water at atmospheric pressure, which is nominally filled to a level $0.4 \mathrm{~m}$ above the top of the heat exchanger tube. The influence of separation plate and ADS 1-3 Spargger in IRWST was ignored in this experiment. Two facility view ports installed on both sides of the tank were provided for visual observation. Heat exchanger tube was a C-shaped tube with $19.05 \mathrm{~mm}$ outside diameter and $1.65 \mathrm{~mm}$ thickness. The material of the pressure vessel, the open water tank, and the heat exchanger tube was 304 stainless steel.

There were 13 sheath thermocouples inserted in the heat exchanger tube, 2 of which were installed at each end of the tube, measuring the inlet and outlet fluid temperatures. Wall and tank water temperatures were measured with

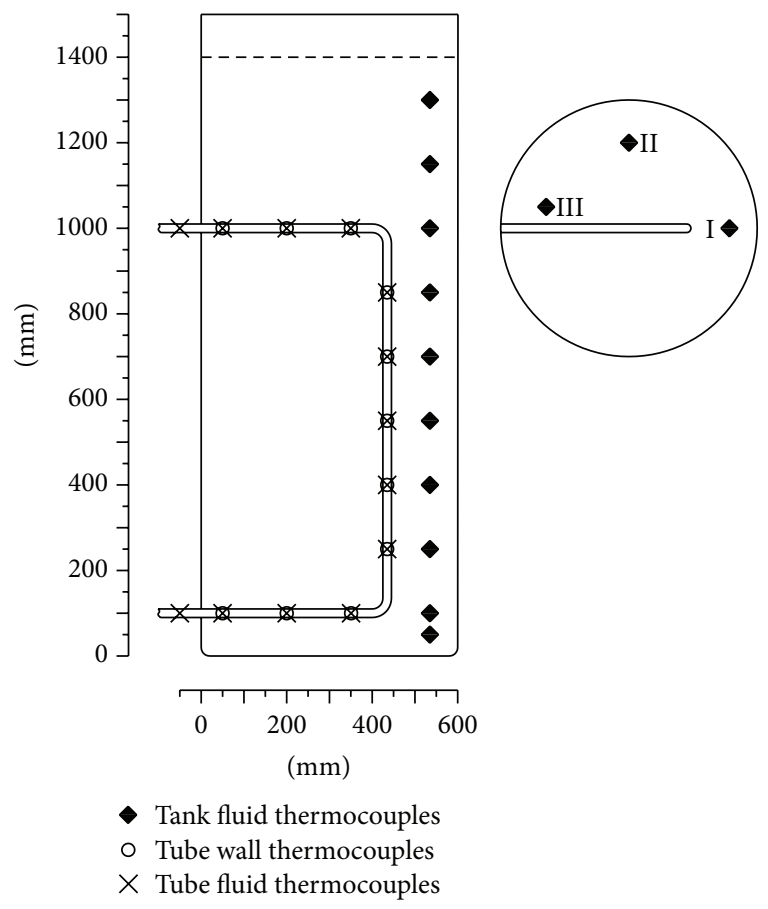

FIGURE 2: Water tank and thermocouple layout.

copper-constantan thermocouples. Four wall thermocouples were welded on each position of the tube outer surface to get an average wall temperature. As shown in Figure 2, tank water thermocouples were located at 3 different positions along vertical direction of tank. The arithmetic mean of the 3 positions at each elevation was used as the average tank fluid temperature of the elevation in the data reduction process. 
TABLE 1: Uncertainties of measured parameters.

\begin{tabular}{lc}
\hline Parameters & Uncertainties \\
\hline Tube temperature & $\pm 0.6^{\circ} \mathrm{C}$ \\
Wall and tank temperature & $\pm 0.3^{\circ} \mathrm{C}$ \\
Mass flow rate & $\pm 0.6 \%$ \\
\hline
\end{tabular}

Electrical signals from the transducers were processed by a data acquisition system. The tube side fluid was heated by 2 electric heating jackets rated at $8 \mathrm{~kW}$. Two Pt100 thermocouples were installed in different areas of the pressure vessel and worked with two temperature controllers to regulate the fluid temperature in pressure vessel. The flow rate in tube was measured by a turbine flow meter installed at the inlet of the heating tube and acquired by the data acquisition system.

Experiments were conducted by following operating procedure which includes initial filling of the tank and the tube loop, remove of dissolved gasses in water, heatup of pressure vessel, beginning of the test, and recording of experimental data. The fluid used in the investigation was distilled water. It was necessary to remove dissolved gasses before the experimentation. The degassing process was done by heating liquid in pressure vessel and operating the centrifugal pump. During this process, valve V2 was opened. Continuous bubbling of gases in the water-level indicator represented degassing of liquid. This was carried out until bubbling eased in the indicator, indicating no presence of dissolved gases in the tube loop. At the end of the process, valve V2 was closed. The degassing of tank water was done at the same time; the process continued for several hours. After that, the system was naturally cooled in the room. Since the water tank is open, the dissolved gasses in tank water could not be discharged completely. The degassing procedure was carried out every time before starting a given set of experimental runs.

Instruments were calibrated and the uncertainty of measured parameters was evaluated according to the procedure suggested by Abernethy and Thompson [8]. The results were summarized in Table 1.

\section{Data Reduction}

The heat exchange tube was virtually divided into 14 cells along the longitudinal direction of the tube, 4 cells for the upper horizontal section, 6 for the vertical section, and 4 for the lower horizontal section. The calculation was conducted in each of the 14 cells to obtain the heat flux and heat transfer coefficients along the tube. The calculation model diagram of the $i$ th cell is shown in Figure 3.

The primary measurements of the experiment include the tube flow rates, tube fluid axial temperature distribution, tube outside wall temperatures, and tank fluid temperatures, which were measured at different locations within the tank.

The tube inside fluid temperatures were used to calculate the heat transfer rate over the length of the cell

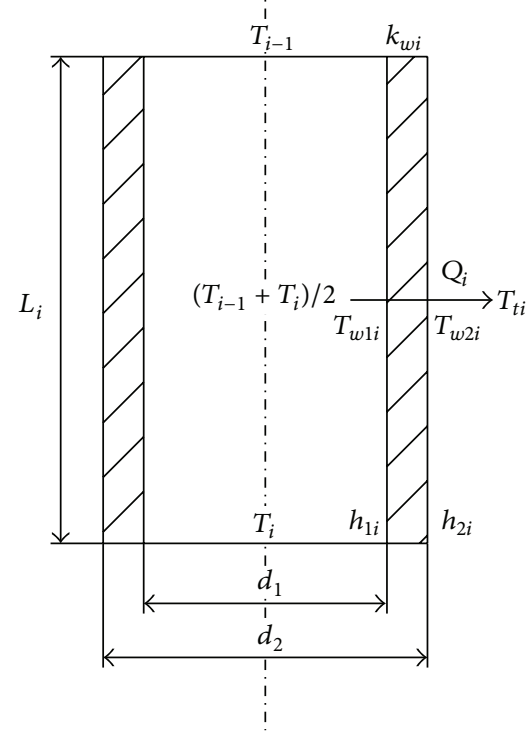

Figure 3: Calculation model diagram of the $i$ th cell.

by using the steady-state one-dimensional energy balance equation:

$$
Q_{i}=W\left(H_{i-1}-H_{i}\right),
$$

where $H_{i}=$ specific enthalpy of the $i^{\prime}$ th cell as determined from the tube inside fluid temperature, $\mathrm{J} / \mathrm{kg}, W=$ tube mass flow rate, $\mathrm{kg} / \mathrm{s}$, and $Q_{i}=$ local heat transfer rate, $\mathrm{W}$.

A heat balance from the tube inside wall to the tube outside wall can be written as

$$
Q_{i}=\frac{2 \pi k_{w i} L_{i}\left(T_{w 1 i}-T_{w 2 i}\right)}{\ln \left(d_{2} / d_{1}\right)}
$$

where $T_{w 1 i}$ and $T_{w 2 i}=$ tube inside and outside wall temperature of the $i$ 'th cell, $\mathrm{K}, L_{i}=$ length of the $i^{\prime}$ th cell, $\mathrm{m}, d_{1}$ and $d_{2}$ $=$ inner and outer diameter of the tube, $\mathrm{m}$, and $k_{w i}=$ thermal conductivity of tube material of the $i$ th cell as determined from the arithmetic mean of tube inside wall temperature $T_{w 1 i}$ and tube outside wall temperature $T_{w 2 i}, \mathrm{~W} / \mathrm{m} \cdot \mathrm{K}$.

The $T_{w 1 i}$ was assumed firstly to consult the value of $k_{w i}$. A new inner wall temperature is then calculated using (2). The current and previous values for the inner tube wall temperature are compared and once acceptably close, the revised temperatures are the required results.

The tube side liquid temperature is measured at the centerline of the tube, which is the hottest location in the tube. The correct temperature used for energy balance given in (1) should be the bulk fluid temperature, which is a flow-weighted average temperature. The tube inside flow is a turbulent flow regime which will result in bulk fluid temperatures close to but not equal to the thermocouple readings taken at the centerline of the tubes. 
The approach is based on a normalized $1 / n$th power velocity profile. It is assumed that the temperature distribution is directly proportional to the normalized velocity distribution as

$$
\frac{T_{w}-T(r)}{T_{w}-T_{c}} \approx \frac{v(r)}{v(R)} \approx\left(\frac{r}{R}\right)^{1 / n},
$$

where $T(r)=$ fluid temperature at radial position $r, \mathrm{~K}, T_{w}=$ fluid temperature at wall, approximately equal to tube side wall temperature, $\mathrm{K}, T_{c}$ = fluid temperature measured in the center of the tube, $\mathrm{K}, v(r)=$ local velocity in the tube at radius $r, \mathrm{~m} / \mathrm{s}, v(R)=$ centerline velocity in the tube, $\mathrm{m} / \mathrm{s}, r=$ local radial position in the tube, $\mathrm{m}, R=$ tube inside radius, $\mathrm{m}$, and $n=$ power fit for velocity profile.

The ratio of the wall-to-bulk temperature to the wall-tocenterline temperature can then be calculated as

$$
\frac{T_{w}-T_{b}}{T_{w}-T_{c}}=\frac{\int_{0}^{R}(r / R)^{1 / n}\left(\left(T_{w}-T(r)\right) /\left(T_{w}-T_{c}\right)\right) r d r}{\int_{0}^{R}(r / R)^{1 / n} r d r}
$$

where $T_{b}=$ tube inside bulk fluid temperature, used to determine the specific enthalpy in (1), K.

The resulting temperature ratio is then given as

$$
\frac{T_{w}-T_{b}}{T_{w}-T_{c}}=\frac{2 n+1}{2 n+2}=0.9375 \quad(n=7) .
$$

Equation (5) indicates that the measured centerline temperature is approximately equal to the bulk temperature. The appropriate value for $n$ is given in Schlichting [9].

The tube inside convective heat transfer coefficient is then calculated along the tube using the wall heat flux, the tube inside bulk fluid temperature, and the extrapolated outside wall temperature:

$$
\frac{1}{h_{1 i}}=\pi d_{1} L_{i} \frac{T_{i}-T_{w 2 i}}{Q_{i}}-\frac{d_{1}}{2 k_{w i}} \ln \frac{d_{2}}{d_{1}},
$$

where $h_{1 i}=$ tube inside heat transfer coefficient of the $i$ th cell, $\mathrm{W} / \mathrm{m}^{2} \mathrm{~K}, T_{i}=$ tube inside bulk fluid temperature of the $i$ 'th cell, equal to $T_{b}$ in (4), $\mathrm{K}, T_{t i}=$ tube outside fluid temperature of the $i$ 'th cell, equal to the arithmetic mean of thermocouple readings of different positions (I, II, and III) in the tank, K.

The tube outside convective heat transfer coefficient is calculated using the heat balance between tube outside wall and tank fluid:

$$
\frac{1}{h_{2 i}}=\pi d_{2} L_{i} \frac{T_{w 2 i}-T_{t i}}{Q_{i}},
$$

where $h_{2 i}$ is the tube outside heat transfer coefficient of the $i$ th cell.

The calculation steps were completed through a data reduction program. The program takes raw test data, calculates the wall heat flux, inside wall temperature, and heat transfer coefficients on both sides of tube, and compares
TABLE 2: Summary of test conditions.

\begin{tabular}{lcccc}
\hline $\begin{array}{l}\text { Duration } \\
(\mathrm{s})\end{array}$ & $\begin{array}{c}\text { Inlet } \\
\text { temperature } \\
(\mathrm{K})\end{array}$ & $\begin{array}{c}\text { Flow } \\
\text { rate } \\
(\mathrm{L} / \mathrm{s})\end{array}$ & $\begin{array}{c}\text { Tank fluid initial } \\
\text { temperature } \\
(\mathrm{K})\end{array}$ & $\begin{array}{c}\text { Tank fluid } \\
\text { level } \\
(\mathrm{m})\end{array}$ \\
\hline 11100 & 353.15 & 0.8 & $286.61(13.46)$ & 1.4 \\
\hline
\end{tabular}

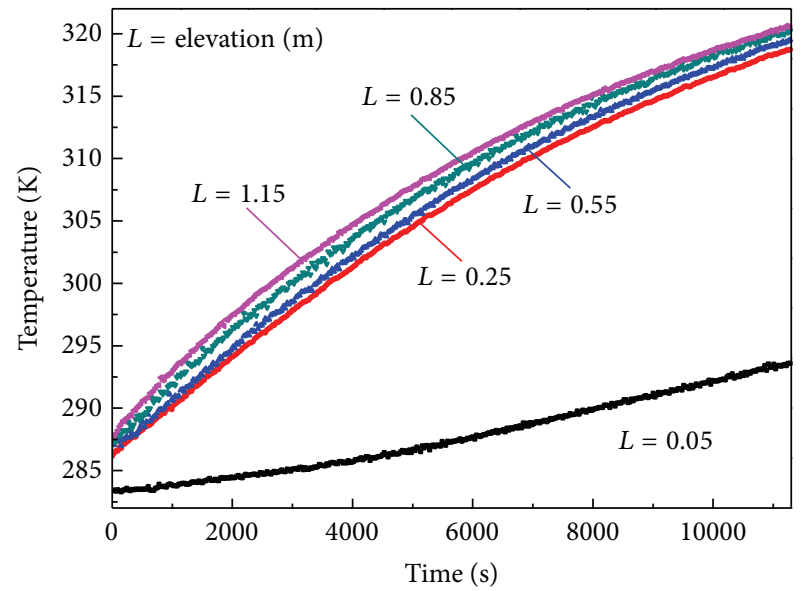

FIgURE 4: Tank fluid temperatures at different elevations as a function of time at position I.

the measured heat transfer with the heat transfer coefficients predicted by several selected correlations.

\section{Results and Discussion}

The tests were conducted with the tank initially at or near room temperature. Table 2 provides the nominal conditions for the test. The temperature controller in the pressure vessel was set to $353.15 \mathrm{~K}$ to provide a temperature difference between tube fluid and tank fluid as high as possible. The slight change in tube inside flow rate and tube inlet temperature led to the stability of the Reynolds number. The Reynolds number for the tube inside fluid ranged from $1.73 \times 10^{5}$ to $1.82 \times 10^{5}$ in the test. The reading of the pressure gauge installed on the pressure vessel was about $0.05 \mathrm{MPa}$.

All these instruments worked well during the test. Several tests were conducted under the conditions in Table 2 and the errors of every test were about $5 \%$. So it can be confirmed that the results are correct.

The tests record the temperature distribution in the tank and thereby provide a measure of the mixing within the tank. Figure 4 shows the measured fluid temperatures as a function of time at five elevations of the tank at position I (Figure 2). The elevations at the top of the tank are shown to heat up first and the lower elevations were delayed. This stratified thermal condition was established with the heat exchanger acting as a thermal pump. The tank water was heated along the tube by natural convection. The heat plume, which surrounded the tube, flowed up to the top of the tank as a hot fluid layer. At 


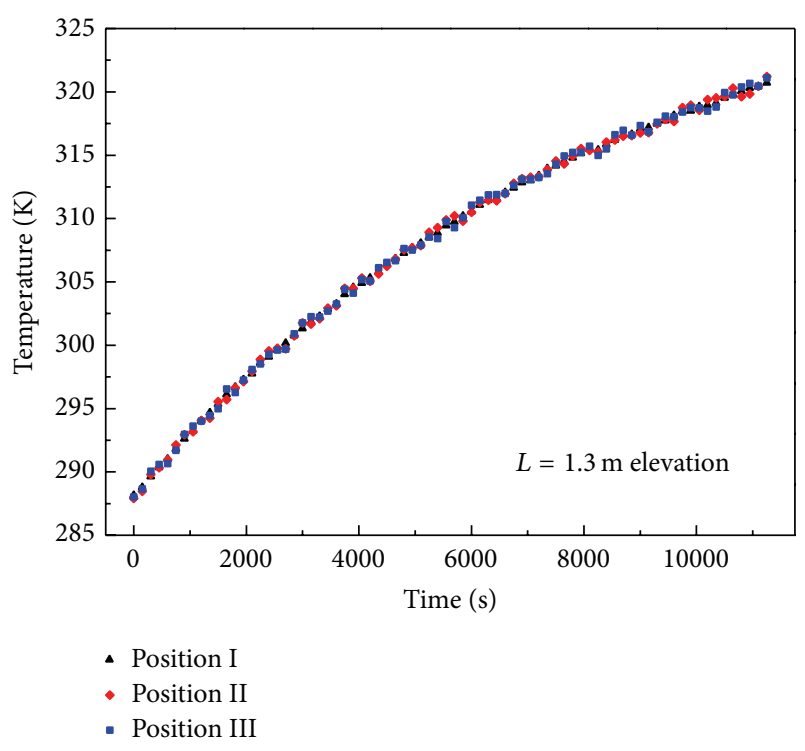

FIGURE 5: Comparison of tank fluid temperature at different position as a function of time.

11280 seconds, the vertical temperature gradient between the top tank elevation $(1.3 \mathrm{~m})$ and bottom elevation $(0.05 \mathrm{~m})$ is about $27 \mathrm{~K}$.

Temperature comparison of the 3 positions (positions I, II, and III) during the test at the $1.3 \mathrm{~m}$ elevation is shown in Figure 5. The small range of temperatures indicates that the tank is well mixed at this elevation. It should be indicated that, at the same elevation, the temperatures of the 3 positions show great similarity with each other.

According to the set flow rates, the Reynolds numbers of the tube internal flow were in the fully turbulent range. The primary-side heat transfer coefficients were calculated using the Dittus-Boelter [10], Petukhov-Popov [11], and Gnielinski [12] single phase forced convection correlations.

(1) Dittus-Boelter Correlation. The Dittus-Boelter correlation is given as

$$
\mathrm{Nu}=\frac{h d_{1}}{k_{f}}=0.023(\mathrm{Re})^{0.8}(\operatorname{Pr})^{0.3}
$$

where $k_{f}=$ fluid thermal conductivity, $\mathrm{W} / \mathrm{m} \cdot \mathrm{K}, \mathrm{Re}=$ Reynolds numbers of tube internal flow, $\operatorname{Pr}=$ Prandtl number of tube internal flow.

The fluid physical properties are determined by the average bulk temperature of each cell of the tube.

(2) Petukhov-Popov Correlation. The Petukhov-Popov correlation is given as

$$
\mathrm{Nu}=\frac{h d_{1}}{k_{f}}=\frac{(f / 8) \operatorname{Re} \operatorname{Pr}}{K_{1}+K_{2}(f / 8)^{1 / 2}\left((\operatorname{Pr})^{2 / 3}-1\right)},
$$

where $f=(1.82 \mathrm{lg} \operatorname{Re}-1.64)^{-2}, K_{1}=1+3.4 f$, and $K_{2}=$ $11.7+1.8 \operatorname{Pr}^{-1 / 3}$.

(3) Gnielinski Correlation. The Gnielinski correlation is given as

$$
\begin{aligned}
\mathrm{Nu} & =\frac{h d_{1}}{k_{f}} \\
& =\frac{(f / 8)(\operatorname{Re}-1000) \operatorname{Pr}_{f}}{1+12.7(f / 8)^{1 / 2}\left(\operatorname{Pr}_{f}^{2 / 3}-1\right)}\left[1+\left(\frac{d_{1}}{L}\right)^{2 / 3}\right] c_{t},
\end{aligned}
$$

where $c_{t}=\left(\operatorname{Pr}_{f} / \operatorname{Pr}_{w}\right)^{0.01}, \operatorname{Pr}_{f} / \operatorname{Pr}_{w}=0.05 \sim 20$, and $f=$ $(1.82 \lg \mathrm{Re}-1.64)^{-2}$.

Subscripts $f$ and $w$ represent fluid Prandtl number calculated with fluid average temperature and wall temperature.

The test data have been analyzed to determine the applicability of these correlations. Figure 6 shows the comparison of the Dittus-Boelter correlation, the Petukhov-Popov correlation, and the Gnielinski correlation with the test determined tube inside wall heat transfer coefficient along the heat exchanger tube at different times.

Since there are no thermocouples melted on the elbows, the heat transfer coefficient of the elbow cells is not shown in Figure 6. As can been seen from Figure 6, the heat transfer coefficients from all these correlations overpredict the experimental data. Petukhov-Popov correlation and Gnielinski correlation overpredict the data by almost $7 \%$ and $16 \%$. The generally more accepted single-phase convective heat transfer Dittus-Boelter correlation provides more agreements with the experimental data, particular in the later period of the test. These comparisons indicate that the Dittus-Boelter correlation is more acceptable than the other two correlations for calculating primary-side heat transfer.

The heat exchanger tube was cooled by natural convection heat transfer in present test. Correlations calculating the natural convection heat transfer coefficients of tube outersurface have been proposed in many literatures. The applicability of the correlations in literatures was controversial because all these correlations were developed originally for conditions different from this paper. Correlations in interrelated literatures are summarized as follows.

(1) Langmuir and Churchill-Chu Correlations [3]. The Langmuir correlation is developed for single-phase natural convection along a horizontal tube and is given by

$$
h=\frac{k_{f}}{d_{2}} \frac{2}{\log (1+(2 / \mathrm{Nu}))},
$$

where $\mathrm{Nu}=0.518 f^{0.25}\left(1+3.47 \times 10^{-7} f\right)^{1 / 12}, f=\operatorname{Ra} F 1(\operatorname{Pr})$, and $F 1(\operatorname{Pr})=\left[1+(0.559 / \operatorname{Pr})^{9 / 16}\right]^{-16 / 9}$.

$\mathrm{Ra}$ is the Rayleigh number where the tube outer diameter is used as the characteristic length. 


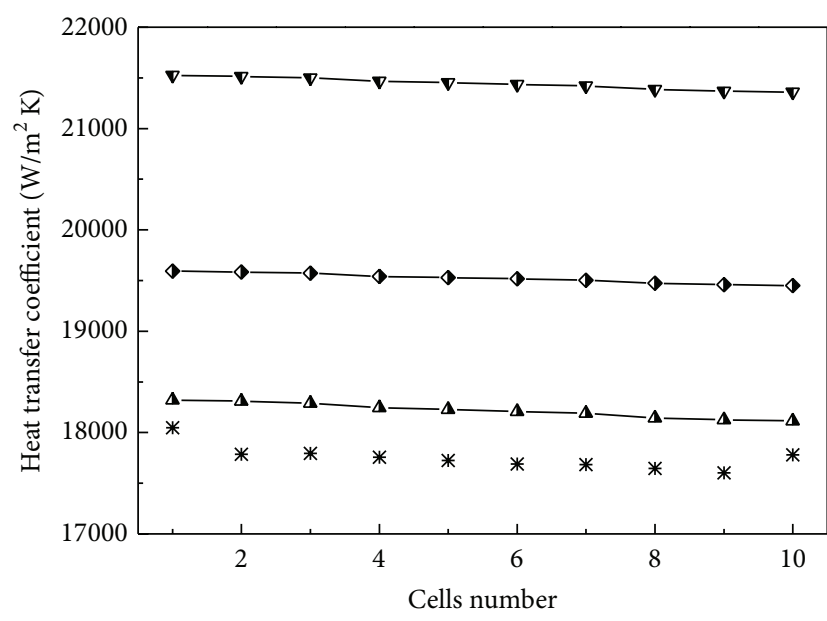

(a) $0 \mathrm{~s}$

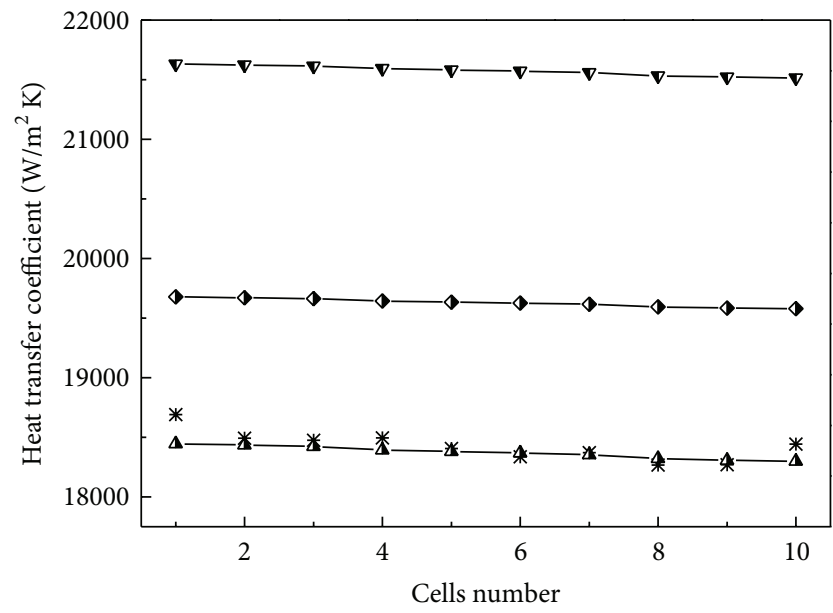

* Experimental data

- $\mathbf{-}$ - Dittus-Boelter correlation

$-\downarrow-$ Petukhov-Popov correlation

- - - Gnielinski correlation

(c) $6000 \mathrm{~s}$

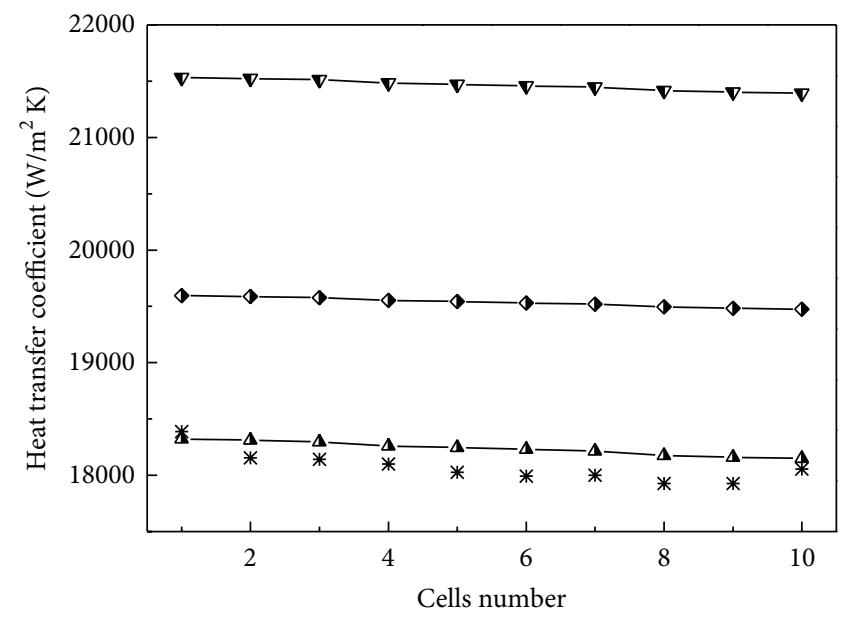

(b) $3000 \mathrm{~s}$

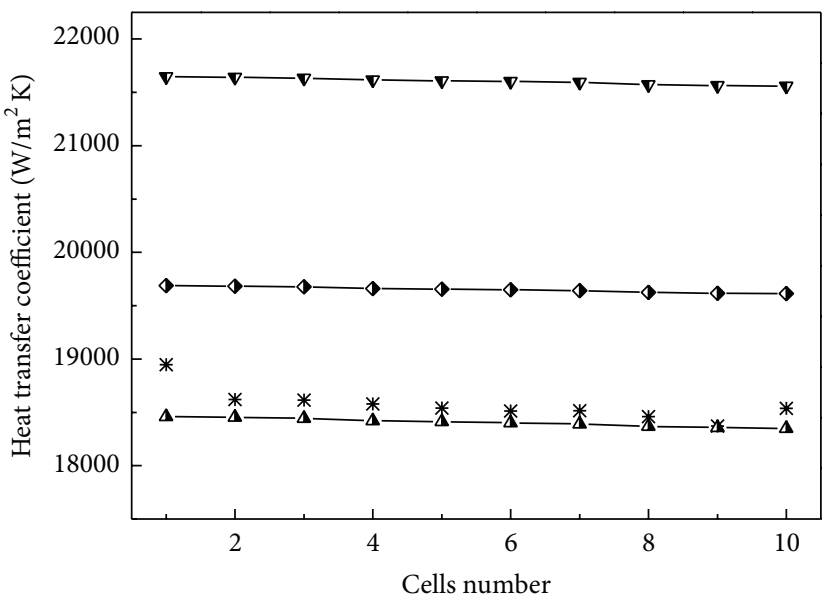

* Experimental data

- $\mathbf{\Delta -}$ Dittus-Boelter correlation

$\checkmark-$ Petukhov-Popov correlation

-v- Gnielinski correlation

(d) $9000 \mathrm{~s}$

Figure 6: Comparison of tube inside heat transfer coefficients with single phase correlations in different cells along the heating tube at different times.

The Churchill-Chu correlation was used for the natural convection along the vertical part of the tube:

$$
\mathrm{Nu}=0.15(\mathrm{Ra} \cdot \mathrm{F} 2(\mathrm{Pr}))^{1 / 3},
$$

where $F 2(\operatorname{Pr})=\left[1+(0.492 / \operatorname{Pr})^{9 / 16}\right]^{-16 / 9}$.

The elevation from the lower horizontal section of the tube was used as the characteristic length for this correlation. This correlation is applicable to Grashof numbers $>10^{10}$.

(2) MARS Code Correlations [5]. The McAdam correlation was used in the MARS code for horizontal region of the heat exchanger tube:

$$
\begin{array}{cl}
\mathrm{Nu}=0.54 \mathrm{Ra}^{0.25} & \left(10^{4} \leq \mathrm{Ra}<10^{7}\right), \\
\mathrm{Nu}=0.15 \mathrm{Ra}^{0.333} & \left(10^{7} \leq \mathrm{Ra}<10^{11}\right) .
\end{array}
$$

For the natural convection along the vertical part of the tube, the correlation of Churchill-Chu was used:

$$
\mathrm{Nu}^{1 / 2}=0.825+\frac{0.387 \mathrm{Ra}^{1 / 6}}{\left(1+(0.492 / \mathrm{Pr})^{9 / 16}\right)^{8 / 27}} .
$$

(3) McAdams Correlations [13]. The more commonly used McAdams correlations for natural convection heat transfer calculation are also compared with the experimental data in this paper.

McAdams correlation for horizontal section of tube is, respectively, given by

$$
\mathrm{Nu}=0.53(\mathrm{Gr} \cdot \mathrm{Pr})^{1 / 4} .
$$




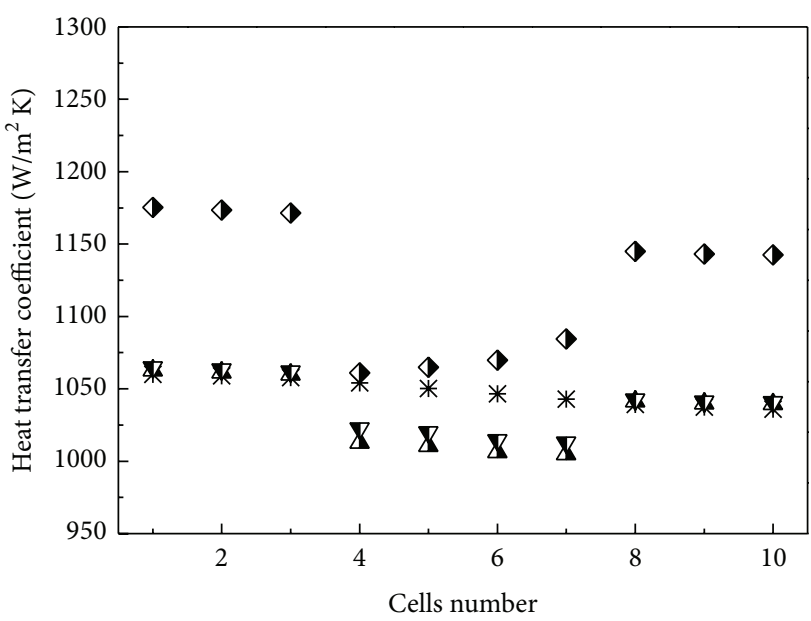

(a) $0 \mathrm{~s}$

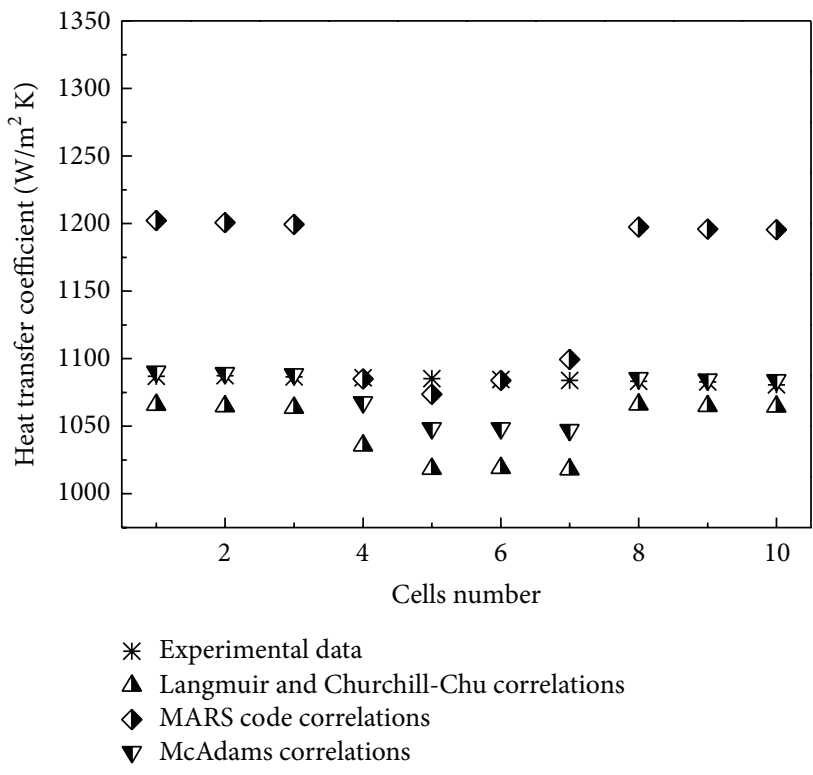

(c) $6000 \mathrm{~s}$

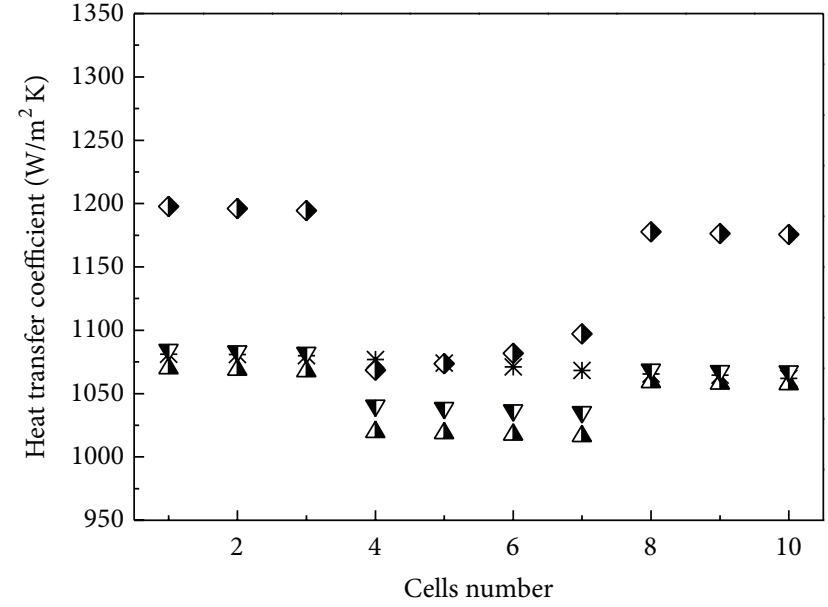

(b) $3000 \mathrm{~s}$

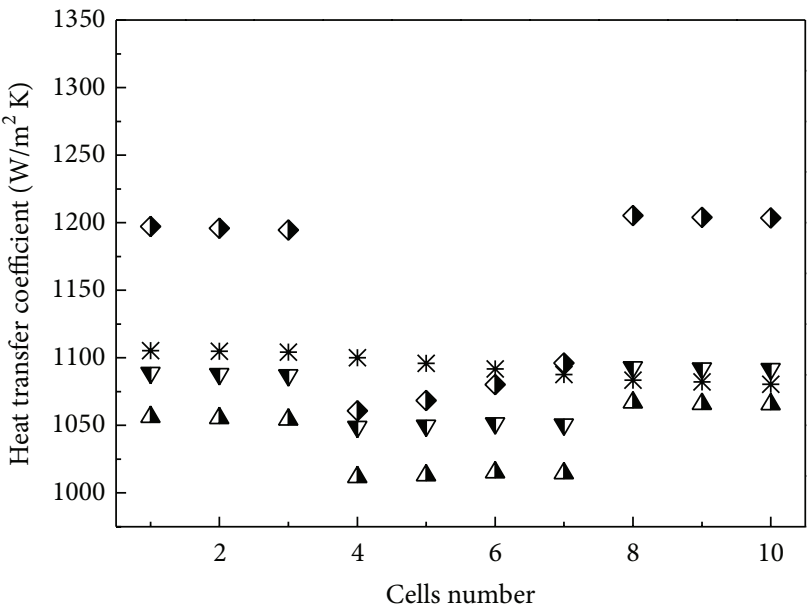

* Experimental data

ム Langmuir and Churchill-Chu correlations

$\checkmark$ MARS code correlations

$\nabla$ McAdams correlations

(d) $9000 \mathrm{~s}$

FIGURE 7: Comparison of tube outside heat transfer coefficients with natural convection correlations in different cells along the heating tube at different times.

For vertical section of tube,

$$
\mathrm{Nu}=0.13(\mathrm{Gr} \cdot \mathrm{Pr})^{1 / 3}, \quad\left(\mathrm{Gr} \cdot \mathrm{Pr}>10^{9}\right) .
$$

Gr is the Grashof number of tube outside fluid.

The fluid physical properties in these correlations are determined by the average temperature of measured tube outer wall temperature and tube outer fluid temperatures.

Figure 7 shows the comparison of the measured heat flux to the heat flux calculated using the natural convection correlations mentioned above.

Cells 1-3 and cells 8-10 in Figure 7 are cells in the upper horizontal section and the lower horizontal section. Cells 4-7 are in the vertical section of the C-shaped heating tube. From Figure 7, the heat transfer coefficients calculated with natural convection correlations in literatures are not continuous along the tube. This is caused by the difference of the correlation used for horizontal region and vertical region calculation.

As can be seen in Figure 7, for the horizontal cells, McAdams correlations represent a better fit. The average relative error of the horizontal cells between McAdams correlations and the experimental data of the 4 moments in Figure 7 is $0.55 \%$. Heat transfer coefficients calculated with vertical correlation in MARS code are closer to the experimental data and the average error is $1.46 \%$. But the vertical section of MARS code correlation predicts an increase trend of heat transfer coefficient along the tube, which is not agreeable with the experimental data. According to Figure 7, the vertical section of McAdams correlations shows a second best-estimate fit with the experimental data; the average error is $3.28 \%$. The comparison indicates that McAdams 
correlations represent a closer fit and more reasonable trend with the experimental data. All these correlations mentioned above are deduced through different experimental data. They have their own applied ranges. This leads to the error between correlation results and experimental results.

\section{Conclusions}

(1) The fluid temperatures in the tank decrease with the decrease of elevation in the vertical direction. In the horizontal directions, the temperatures are nearly uniform.

(2) Dittus-Boelter correlation is more acceptable than the Petukhov-Popov correlation and Gnielinski correlation for calculating tube-side heat transfer.

(3) The heat exchanger tube was cooled by natural convection heat transfer. As compared to the experimental data, the McAdams correlations represent a closer fit and more reasonable trend than Langmuir and Churchill-Chu correlations and MARS code correlations for calculation of tube outside heat transfer.

\section{Conflict of Interests}

The authors declare that there is no conflict of interests regarding the publication of this paper.

\section{References}

[1] S. N. Tower, T. L. Schulz, and R. P. Vijuk, "Passive and simplified system features for the advanced westinghouse $600 \mathrm{MWe}$ PWR," Nuclear Engineering and Design, vol. 109, no. 1-2, pp. 147$154,1988$.

[2] T. L. Schulz, "Westinghouse AP1000 advanced passive plant," Nuclear Engineering and Design, vol. 236, no. 14-16, pp. 15471557, 2006.

[3] T. Yonomoto, Y. Kukita, and R. R. Schultz, "Heat transfer analysis of the passive residual heat removal system in ROSA/AP600 experiments," Nuclear Technology, vol. 124, no. 1, pp. 18-30, 1998.

[4] A. Gupta, V. Eswaran, P. Munshi, N. K. Maheshwari, and P. K. Vijayan, "Thermal stratification studies in a side heated water pool for advanced heavy water reactor applications," Heat and Mass Transfer, vol. 45, no. 3, pp. 275-285, 2009.

[5] J.-J. Jeong, K. S. Ha, B. D. Chung, and W. J. Lee, "Development of a multi-dimensional thermal-hydraulic system code, MARS 1.3.1," Annals of Nuclear Energy, vol. 26, no. 18, pp. 1611-1642, 1999.

[6] Y. J. Chung, S. H. Yang, H. C. Kim, and S. Q. Zee, “Thermal hydraulic calculation in a passive residual heat removal system of the SMART-P plant for forced and natural convection conditions," Nuclear Engineering and Design, vol. 232, no. 3, pp. 277-288, 2004.

[7] Y. J. Chung, I. S. Jun, S. H. Kim, S. H. Yang, H. R. Kim, and W. J. Lee, "Development and assessment of system analysis code, TASS/SMR for integral reactor, SMART," Nuclear Engineering and Design, vol. 244, pp. 52-60, 2012.

[8] R. B. Abernethy and J. W. Thompson, Handbook Uncertainty in Gas Turbine Measurements, Arnold Engineering Development Center, Arnold Air Force Station, Manchester, Tenn, USA, 1973.
[9] H. Schlichting, Boundary Layer Theory, McGraw-Hill, New York, NY, USA, 4th edition, 1960.

[10] J. H. Lienhard, A Heat Transfer Text Book, Phlogiston Press Cambridge, Massachusetts, Mass, USA, 3rd edition, 2008.

[11] B. S. Petukhov, "Heat transfer and friction in turbulent pipe flow with variable properties," Advances in Heat Transfer, vol. 6, pp. 503-564, 1970.

[12] V. Gnielinski, "New equations for heat and mass transfer in turbulent pipe and channel flow," International Journal of Chemical Engineering, vol. 16, no. 2, pp. 359-368, 1976.

[13] W. H. McAdams, Heat Transmission, McGraw-Hill, New York, NY, USA, 3rd edition, 1954. 


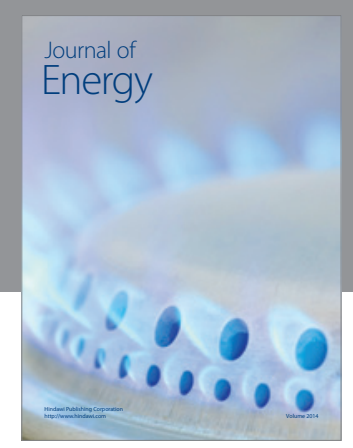

Journal of

Industrial Engineering
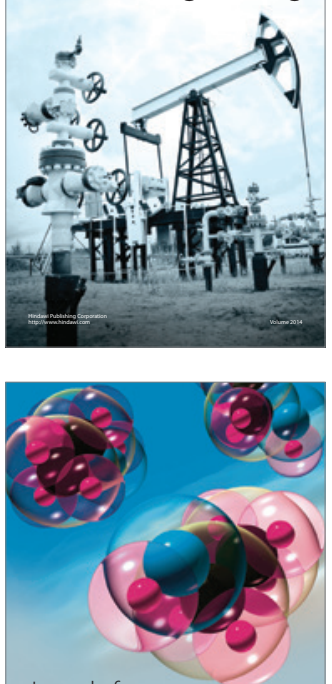

Fuels
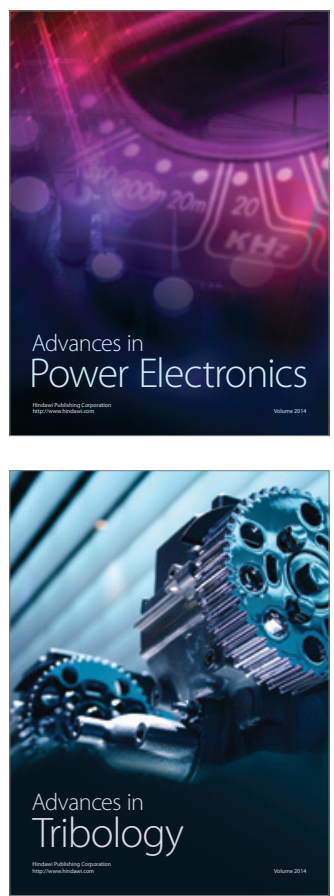

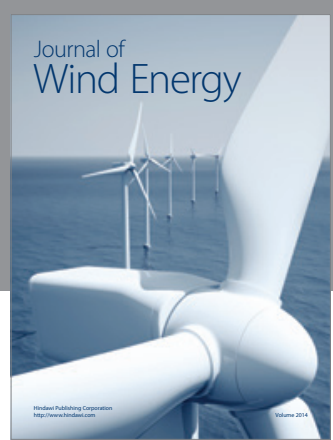

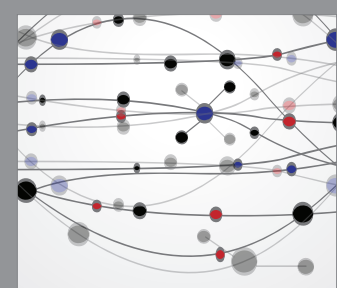

The Scientific World Journal

Submit your manuscripts at http://www.hindawi.com

Journal of

Structures
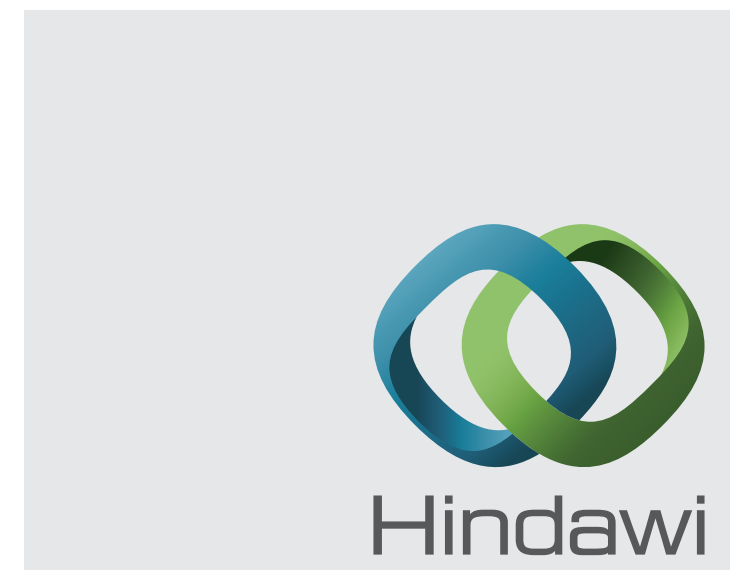

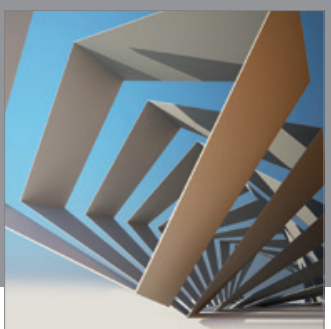

Rotating

Machinery
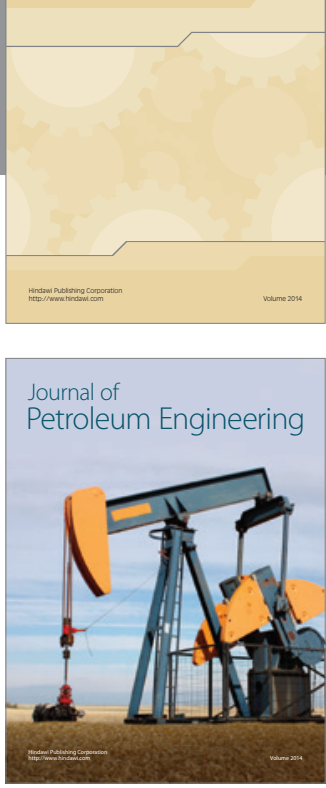

Journal of

Solar Energy
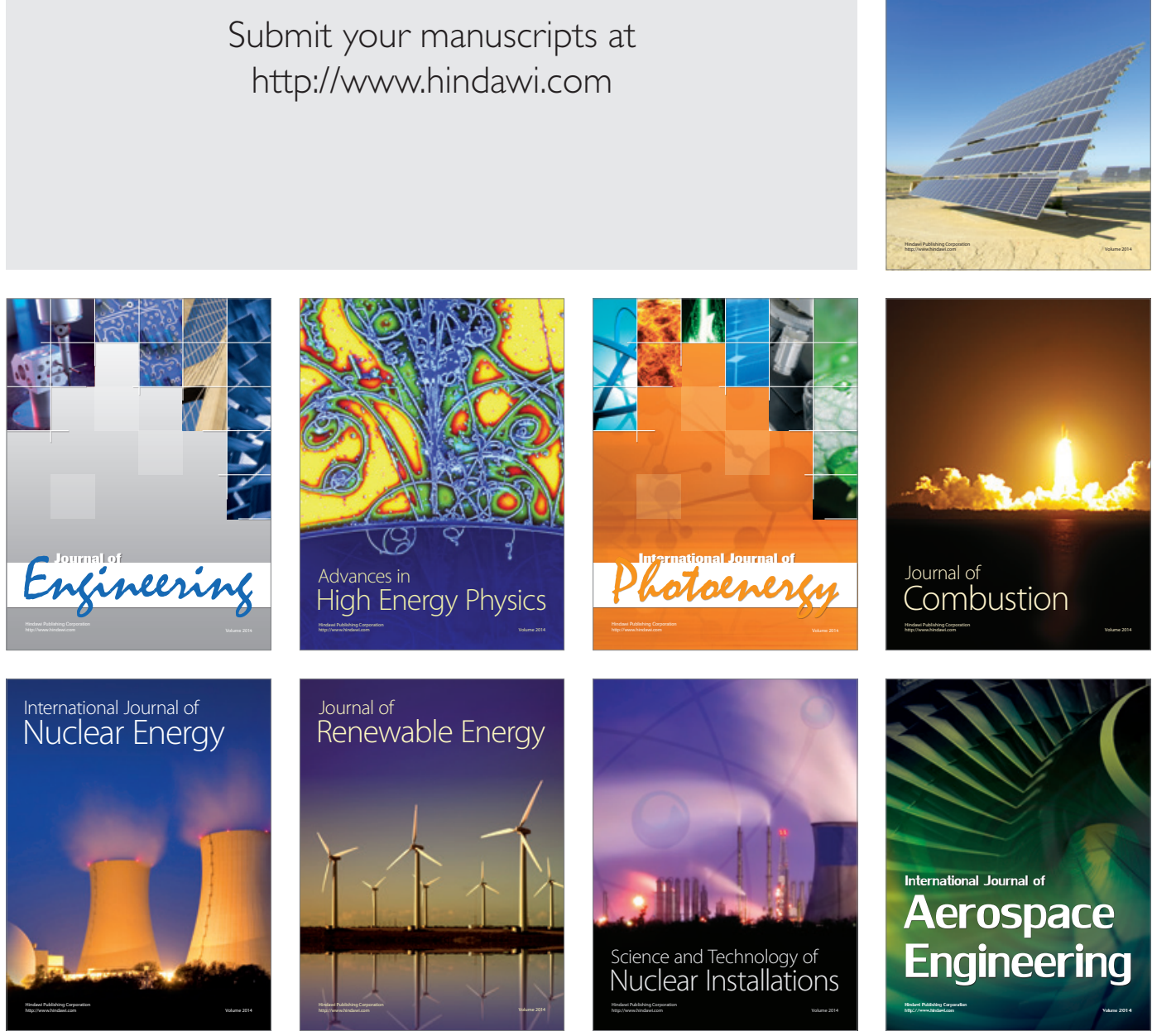